\title{
Estimation of Effectiveness of the International Quality Management System Implementation on the Example of an Industrial Enterprise
}

\author{
Vera Dmitrievna Borisova ${ }^{1}$, Sergey Mihailovich Vasin ${ }^{1}$, Nvard Eduardovna Petrosyan ${ }^{1}$, Konstantin Yurevich \\ Korolev $^{1}$, Ruslan Rustamovich Zhalilov ${ }^{1} \&$ Ludmila Ivanovna Kryukova $^{1}$ \\ ${ }^{1}$ Penza State University, Krasnaya, Russian Federation \\ Correspondence: Vera Dmitrievna Borisova, 440026, Krasnaya, 40, Penza, Russian Federation.
}

Received: November 30, 2014 Accepted: February 19, 2015 Online Published: May 22, 2015

doi:10.5539/ass.v11n14p228 URL: http://dx.doi.org/10.5539/ass.v11n14p228

\begin{abstract}
The article considers the creation of the quality management system at an enterprise as an innovative investment project. That is why to estimate the effectiveness of the Quality Management System estimation methods of investment project effectiveness are used. The authors come to the conclusion of a substantial increase in profits due to the Quality Management System functioning.
\end{abstract}

Keywords: estimation of investment project effectiveness, quality management system, internal rate of return, net discount profit

\section{The Introduction}

At the moment the State's primary task is to generate the conditions for innovation. In this case you cannot miss neither the new science intensive nor traditional types of production which, having risen to a new technological level, can become "engines" transferring the economy to innovative "tracks". The "engines", first and foremost, include machine-building which is the so-called "circulatory system" of the national economy, in particular, the production of pipeline fittings as an essential part of most industrial systems. The effective development of such important for the national economy industries like oil and gas, nuclear energy is impossible without solving a number of problems of high-technological pipeline fittings ("Animation is not expected", 2009).

Nowadays many Russian companies produce goods according to the old methodology, using the old equipment, spending a lot of money on staff, maintenance and energy supply (luckily, the prices for the latter are still relatively low).

On the other hand, any company, whatever may happen to it, has the potential to significantly reduce staff, rent, heating, and energy supply costs, as well as capital expenditures. Due to this, the company will be more economical, flexible and efficient. All these factors directly affect the selling price of products and, therefore, competitiveness.

From the point of view of economics, the present time is the most suitable for optimizing organization and production processes, because it is possible to purchase new, second-hand or restored western equipment at a reduced price. Delivery of new equipment is significantly quicker now compared to the period prior to the "new economic situation".

The decisive factors for sustainable market position and competitiveness of enterprises are not only the supply and demand on the market, but also such internal indicators as:

-technological level of products;

-qualification of personnel;

-the quality of the products;

-information management (application in information and communication technologies);

-research and development, patents, licenses;

-general management; organizational structure; finance.

The base for the innovation is: invention+production+qualification+introduction=innovtion 
Innovations at the enterprise are spread over all types of the enterprise activity and they should be considered as a complex:

Enterprise production cycle. Competitiveness and flexibility. Strategic planning. Innovations, innovation management. Enterprise innovation potential.

It means:

-analysis of efficiency and automation level of the production and organizational process;

- comparative analysis of the quality of products, service, warranty service and maintenance;

-know-how of research and development;

-liquidity and investment potential;

-experience in innovation management.

Product innovation:

- new products on the market;

- new products for the enterprise; essential product changes; new "old" products;

- related services as part of the product; innovations in the production process;

- technology renovation, productivity improvement;

-changes in the value chain / depth of the production process;

-updating of organizational processes in order to increase their productivity;

-reducing the way and simplifying the decision-making process, creating flatter hierarchical structures;

-significant changes in the technological / organizational work processes;

-new tools for planning and management; innovations in the social sphere:

-updating models of remuneration and personnel motivation system;

-introducing a system of continuous professional development;

-implementing new management strategies / new mechanisms of delegating responsibility and administration;

-economic manufacturing / management;

-new forms of team contracts.

Factors contributing to innovation are the expansion and systematization of experience in the field of research and development, application of global technological development and improvement of the link between the production, research and development. Furthermore, it is of great importance to optimize links between the enterprise and markets, to change organizational processes and structures, as well as to consolidate enterprises and to develop cooperation.

Thus, it can be seen that a single "innovation" such as installation of the most modern machine tools does not automatically lead to tangible changes in the field of competitiveness and the improvement of protection against crises, as in reality innovation must be seen as a complex, systematic process of the enterprise (Indrisov, 1997, pp. 28-29).

The basis of evaluation of the effectiveness of the innovative project is a comparative analysis of the scope of the proposed investment and future cash flows. Comparable values refer in most cases to different time periods. Therefore, the most important issue in this caseas well as in determining the cost-effectiveness of new equipment and technology is the problem of comparing the income and expenses and keep them in a comparable form (Indrisov, 1997). The causes of the discounting process (i.e. bringing in a comparable form) may be inflation, unwanted dynamics of investments, the decline in industrial production, different forecasting horizons, changes in the tax system, etc.

Methods for evaluating the effectiveness of the project are subdivided into two groups based on discounted and accounting estimates.

Methods for evaluating the effectiveness of the project, based on accounting estimates (undiscounted) are payback period (PP), accounting rate of return (ARR) and debt service coverage ratio (DCR).

Methods for evaluating the effectiveness of the project, based on discounted estimates are significantly more accurate because they take into account different types of inflation, changes in interest rate, rate of return, etc. 
These indicators include the method of profitability index (PI), the net value, otherwise known as "net present value" (NPV), and internal rate of return (IRR).

Our studies have shown that traditional methods of project evaluation are widely used in financial practice.

The method of return on investment is very common. But ignoring the future time value of money and thus the inapplicability of discounting is its significant disadvantage. In the condition of inflation, sharp fluctuations in interest rates, and lower rate of domestic savings in enterprise in real Russian economy this method is not accurate enough.

The coefficient of efficiency of investments, understood as the average profitability for the entire duration of the project, calculated by dividing the average annual return on the average annual value of investments. This indicator is compared with net profit ratio of invested capital (total average net balance) (Skripko, 2010).

\section{The Method}

However, all three traditional indicators, based on an accounting estimate do not take into account the temporal component of cash flows. They are not joined to a factor analysis and cash flow dynamics in economic reality. So you can more fully evaluate the project, using the methods based on discounted estimates (Zinchenko et al., 2009).

In accordance with the Guidelines on estimation of investment projects effectiveness \#BK 477 of June 21, 1999, the base for estimating the commercial efficiency of the investment project effectiveness or operation of a going concern is the so -called stream of real money:

$$
P_{t}=R_{t}-C_{t} \mathrm{t}=0
$$

where:

$R_{t}$ - financialresults, obtained on the t-m step of the project (functioning of the enterprise);

$\mathrm{C}_{t}$ - total costs of operations on the t-m step of the project (functioning of the enterprise);

$\mathrm{T}$ - temporal horizon of commercial efficiency calculation .

We assume that a company intends to introduce the system of quality management using an internationally popular ISO 9000 system of certification. Before the introduction of quality management arrangement within the chosen time span the anticipated flow of real money from investment and functional activities is P $0 \mathrm{t}=\mathrm{R} 0 \mathrm{t}$ - C $0 \mathrm{t}$. With setting up quality management system viewed as a separate investment project and values DC $t$ and DR $\mathrm{t}$ denoting direct costs and results correspondingly, the processes of quality management introduction and further development may be presented as follows:

$$
P_{t}=\left(R^{o}{ }_{t}+D R_{t}^{o}\right)-\left(C_{t}^{o}+D C_{t}-D C_{t}\right), t=0, T .
$$

Costs for the creation of the QMS DCt include recurrent (investment) costs of repair facilities and purchase of equipment for training (teaching) staff, as well as to pay the costs of consulting assistance and auditing for compliance with the international standard ISO 9000.

A commercial result from the implementation of the $\mathrm{QMS}_{\mathrm{DR}}$ is generally manifested in the functioning of the system due to the total cost savings of the enterprise $\mathrm{DC}_{t}$ compared to the baseline $\mathrm{C}_{t}$, on the one hand, and to further increase of the total financial results $D_{t}$ relative to the base level of $R_{t}$, on the other hand .Thus $D R t=$ $\mathrm{DC}_{\mathrm{t}}+\mathrm{DR}_{\mathrm{t}}$, and the expression for real money flow from investing and operating activities of the enterprise in the conditions of implementation and subsequent operation of the QMS takes the following form:

$$
P_{t}=\left(R_{t}^{o}+D R_{t}^{o}\right)-\left(C_{t}^{o}+D C_{t}-D C_{t}\right), t=0, T .
$$

Dynamics of the costs flow for establishing the QMS and the flow of financial results from its introduction shows that the commercial effect of the QMS begins to emerge with a certain lag in relation to expenses:

$$
D_{t}(r)=\sum_{t=0}^{T} P_{t} /(1+r)^{t}
$$

Net present value (NPV) of the enterprise for the entire reporting period is determined by the known formula (5):

$$
D_{t}(r)=D_{T}^{0}(r)+\sum_{t=0}^{T} P_{t} /(1+r)^{t}
$$

Where $r$ - the discount rate, characterized by the time value of money (TVM).

Since $P_{t}=P_{t}+D P_{t}$, we have (6): 


$$
D_{t}(r)=\sum_{t=0}^{T}\left(\Delta R_{t}^{0}+\Delta C_{t}^{0}\right) /(1+r)^{t}-\sum_{t=0}^{T} \Delta C_{t} /(1+r)^{t}
$$

Where $D_{t}(r)$ - net present value of the enterprise without the project of creation the QMS.

Creation of the QMS at an enterprise is commercially effective at discount rate $r$ if and only if for some calculation horizon $\mathrm{T}=\mathrm{T}_{\mathrm{R}}$ value $\mathrm{DD}^{\mathrm{rt}}$ ) becomes positive and does not change its sign with a further value increase of T. Value To characterizes the payback period for the creation of the QMS without taking into account the time value of money.

Internal rate of return (IRR) of the company creation project of the QMS is to be usefully measured as discount rate $r_{0}$, bringing the net present value increase due to the introduction of the QMS, to zero at

$\mathrm{T}_{\mathrm{i}} \mathrm{T}_{0}: \operatorname{DDT}_{\mathrm{T}}\left(\mathrm{r}_{0}\right)=0$.

Estimated value of internal rate of return reflects the relative efficiency of investment in the creation of QMS in percent on invested capital, whereas the calculated value of the net present value of growth expresses the absolute profitability of the project taking into account the time value of money. When $r_{0}$ the net present value increase due to the introduction of the QMS, becomes negative.

In general, the project budget for the implementation of quality management system consists of:

1. Consulting firm service costs.

2. Cost of quality management department organization (repair facilities, equipment, etc.).

3. Tuition of the company personnel.

4. Cost of internationally accredited company to conduct the audit work and the issuance of the certificate of conformity ISO 9000.

\section{The Results}

The costs of implementation and operation of the QMS at the JSC "Penztyazhpromarmatura".

Imagine annual capital investments (expenses) for the implementation and operation of the QMS in tabular data (Table 1). The QMS was formed in 2010 when a new management team came to the enterprise, so the analysis begins with this very year.

The QMS functioning gives the company certain advantages, the main ones are:

1) reduction of faulty products; 2) rational allocation of responsibility for quality; 3) accountability and transparency of production, organizational and financial processes, improvement of their logistics relationship; 4) increasing staff motivation; 5) improvement of working conditions and safety; 6) rating growth of the enterprise and maintaining a positive image; 7) output of consistently high quality products ( increase in output of the first grade.

Table 1. Costs on the QMS implementation and functioning

\begin{tabular}{|c|c|c|c|c|}
\hline & 2010 & 2011 & 2012 & 2013 \\
\hline 1. Cost of consulting firm services thous.roubles & 330 & 590 & 280 & - \\
\hline $\begin{array}{l}\text { Cost of the organization of quality management (repair facilities, equipment, etc.), } \\
\text { thous.roubles }\end{array}$ & 600 & - & - & - \\
\hline Cost of enterprise personnel training, thous.roubles & - & - & 60 & 1100 \\
\hline Cost of certification, thous.roubles & - & - & - & - \\
\hline Total investments, thous.roubles & 930 & 590 & 340 & 1100 \\
\hline
\end{tabular}

It should be noted that in most cases the impact of the QMS to the above aspects of the enterprise is indirect.

For example, it is obvious that the presence of an international certificate for the quality management system increases the rating of the company, but there are other factors (policy, effective action service marketing, sales, investment attractiveness, etc.) that influence the rating increase of the enterprise. According to experts from international rating agencies rating upgrade on a $1 \%$ increase in business profits by more than $2 \%$ ("Animation is not expected", 2009).

In connection with the above objective evaluation of the QMS from different perspectives (economic, industrial, environmental, social) is a difficult issue. According to the authors, the problem of assessing the effectiveness of 
the QMS and the contribution to the additional profit from the increase in output of the first grade must be approached from the perspective of expert assessments (Shvets, 2009).

The expert evaluation opinions of managers and specialists of "Penztyazhpromarmatura" showed that the proportion of the contribution of the QMS in an increase in output of higher quality (e.g. rotary metal- metal) is $5 \%$.The technique of the expert assessment of the contribution in an increase in output of the highest quality is to assess the increase in output of higher quality after the implementation of the recommendations and proposals made by the Department of quality management activities of "Penztyazhpromarmatura".

Main recommendations and suggestions received from the QMS are as follows:

1) implement the quality management system ISO 9001-2000;

2) use a more high-grade steel for thermal and nuclear power plants for the Far North conditions (Titu, Oprean, \& Grecu, 2011);

- DN 80-300 OST 24.125.04-89 of stainless steel;

- DN 10-300 OST 34.10-420-90 of stainless steel;

- DN 100-600 OST 24.125.33-89 of carbon steel grades (Titu, Oprean, \& Grecu, 2011);

3) use the module evaluation of the mechanical properties and shipmentof hot rolled coils by statistical method . Statistical non-destructive method to be used for hire, delivered to consumers in rolls. Calculation of quality indicators is made for each coil, the values of quality indicators are automatically entered in the passport and certificate of quality (Militaru \& Ionescu, 2011).

4) set the line for the production and application of anticorrosion coatings on bends, which allows to apply several types of one - and two-component coatings (Durakbasa, Bas, \& Osanna, et al., 2011).

The work on the formation of the company QMS started in 2005, the certificate of compliance with international standards was received in 2008. Therefore, it took four years to implement the quality management system. The basis for comparison is the year 2004. Studies have shown that the introduction of the QMS involves increasing the output of all kinds of top quality products. Positive dynamics of this process reflects the content of Table 2.

Note: Studies have shown that the only negative result of the comparison with the base period for the production of non-return valves, which occurred in 2011, was due to technical reasons.

Table 2. Dynamics of the main kinds of the highest quality products in "Penztyazhpromarmatura"

\begin{tabular}{llllllllll}
\hline ProductType & 2009 & 2010 & & 2011 & & 2012 & & 2013 \\
\hline & thous. ps. & thous. ps. & $\Delta$ by 2009 & thous. ps. & $\Delta$ by 2010 & thous. ps. & $\Delta$ by 2011 & thous. ps. & $\Delta$ by 2012 \\
Ball valves & 164133 & 180363 & 16230 & 166866 & -2733 & 185334 & 21201 & 207798 & 43665 \\
Butterfly Valves & 45148 & 48289 & 3141 & 50015 & 4867 & 55291 & 10143 & 48053 & 2905 \\
Backward valves & 169578 & 177131 & 7553 & 152136 & -17422 & 197394 & 27816 & 205710 & 36132 \\
latches & 5944 & 6226 & 282 & 6477 & 533 & 6874 & 930 & 7212 & 1268 \\
\hline
\end{tabular}

For the calculation of indicators to assess the effectiveness of the project onthe implementation of the QMS it is necessary to determine the amount of additional profits obtained at the increase in production of the highest qualityproducts (Sava (Angheluta) \& Tuclea, 2011). With this purpose we use the data in Table 3.

Table 3. Cost and selling prices for the highest quality products of the JSC "Penztyazhpromarmatura" most in demand

\begin{tabular}{ccccccccc}
\hline Product Type & \multicolumn{2}{c}{2010} & \multicolumn{2}{c}{2011} & \multicolumn{2}{c}{2012} & \multicolumn{2}{c}{2013} \\
\hline & Cost. USD & Price, USD & Cost USD & Price, USD & Cost USD & Price, USD & Cost USD & Price, USD \\
\hline $\begin{array}{c}\text { Ball valves, DN } \\
\quad 350 \mathrm{~mm}\end{array}$ & 5621,50 & 10461,31 & 6316,78 & 7406,14 & 7211,86 & 8307,66 & 8390,35 & 9871,00 \\
$\begin{array}{c}\text { Butterfly Valves, } \\
\text { DN 400 mm }\end{array}$ & 10372,80 & 12421,00 & 10939,13 & 13322,89 & 11474,56 & 13521,15 & 11818,80 & 13926,78 \\
$\begin{array}{c}\text { Checkvalves, DN } \\
\quad 700 \mathrm{~mm}\end{array}$ & 5792,40 & 8189,98 & 6005,42 & 6485,37 & 6414,26 & 7274,49 & 6955,60 & 7904,05 \\
$\begin{array}{c}\text { Gatevalves, DN } \\
350 \mathrm{~mm}\end{array}$ & 6214,10 & 7402,62 & 9015,87 & 9802,35 & 10187,71 & 11024,65 & 11597,10 & 12120,00 \\
\hline
\end{tabular}


Extra profits due to increasing the output of high quality products is determined by the formula [7]:

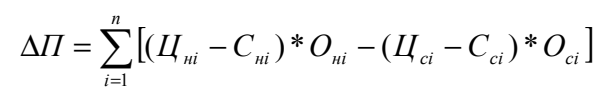

where:

$\Delta \mathrm{P}$ - the total amount of extra profits from the improved product quality, USD;

$\mathrm{n}$ - number of products for which there was improvement in quality;

$\mathrm{Pr}_{\mathrm{ci}}, \mathrm{Pr}_{\mathrm{Hi}}$ - selling price of products respectively of low and high quality of the i-kind, USD;

$\mathrm{C}_{\mathrm{ci}}, \mathrm{C}_{\mathrm{Hi}}$ - the cost of manufacturing production units respectively of low and high quality of the i-type, USD;

$\mathrm{V}_{\mathrm{ci}}, \mathrm{V}_{\mathrm{Hi}}$ - the volume of production and sales in real terms, respectively, before and after the quality improvement (Chauvel, 2012).

The results of calculations of additional profit of the JSC "Penztyazhpromarmatura" obtained from increasing the output of all kinds of top quality products are shown in Table 4.

Table 4. Additional profit gained by increasing the output of the highest quality in 2010-2013, compared to the year 2009

\begin{tabular}{|c|c|c|c|c|c|c|c|c|}
\hline \multirow[t]{2}{*}{ Product Type } & \multicolumn{2}{|c|}{2010 г. } & \multicolumn{2}{|c|}{2011 г. } & \multicolumn{2}{|c|}{2012 г. } & \multicolumn{2}{|c|}{2013 г. } \\
\hline & $\begin{array}{c}\text { Extra profit } \\
(100 \%) \\
\text { USD }\end{array}$ & $\begin{array}{c}\text { Extra profit } \\
\text { QMS, (5\%) } \\
\text { USD }\end{array}$ & $\begin{array}{c}\text { Extra } \\
\text { profit } \\
(100 \%) \\
\text { USD }\end{array}$ & $\begin{array}{c}\text { Extra } \\
\text { profit } \\
\text { QMS, } \\
(5 \%) \text { USD }\end{array}$ & $\begin{array}{l}\text { Extra profit } \\
(100 \%) \text { USD }\end{array}$ & $\begin{array}{c}\text { Extra } \\
\text { profit, } \\
\text { QMS (5\%) } \\
\text { USD. }\end{array}$ & $\begin{array}{l}\text { Extra profit } \\
(100 \%) \text { USD }\end{array}$ & $\begin{array}{c}\text { Extra profit } \\
\text { QMS, (5\%) } \\
\text { USD }\end{array}$ \\
\hline $\begin{array}{c}\text { Ballvalves, DN } \\
350 \mathrm{~mm}\end{array}$ & 6403,709 & 320,185 & 353,158 & 17,658 & 557,162 & 27,858 & 9191,483 & 459,574 \\
\hline $\begin{array}{c}\text { ButterflyValves } \\
\text {, DN } 400 \mathrm{~mm}\end{array}$ & 6433,396 & 321,670 & $\begin{array}{c}11601,75 \\
9\end{array}$ & 580,088 & 20758,560 & 1037,928 & 6123,682 & 306,184 \\
\hline ProductType & 2010 г. & 2011 г. & 2012 г. & 2013 г. & ProductType & 2010 г. & 2011 г. & 2012 г. \\
\hline $\begin{array}{l}\text { Checkvalves, } \\
\text { DN } 700 \mathrm{~mm}\end{array}$ & 2201,473 & 110,074 & $-3568,640$ & - & 11402,608 & 570,130 & 10507,185 & 525,359 \\
\hline $\begin{array}{c}\text { Gatevalves, DN } \\
350 \mathrm{~mm}\end{array}$ & 213,110 & 10,656 & 288,241 & 14,412 & 521,199 & 26,060 & 12,705 & 0,635 \\
\hline$\Delta \mathrm{P}$ total, USD & 15251,69 & 762,585 & 8674,518 & 612,158 & 33239,53 & 1661,976 & 25835,06 & 1291,752 \\
\hline
\end{tabular}

The content of the table also reflects the $5 \%$ part of the additional profits of the enterprise in terms of value received through the effective functioning of the quality management system (QMS).

Thus, the additional profit from the increase in output of the highest quality products due to the introduction of the QMS for 4 years amounted to 4328.471 thousand roubles.

\section{The Conclusion}

The method and the executive calculations can be used for another industrial enterprises in the region and in the country. Further, the method can be used for benefit forecasts when QSM is intruded.

\section{References}

Animation is not expected. (2009). Finance and credit, 9-10, 4-9.

Chauvel, A. M. (2012). The next step to TQM. In the Proceedings 41st Annual EOQ Congress on Quality - A Critical Factor in the Past, Present and Future (pp. 205-209).

Durakbasa, N. M., Bas, G., \& Osanna, P. H. et al. (2011). Sustainable management systems of quality, energy and environment in industry. In the Proceedings of 1st International Conference on Quality and Innovation in Engineering and Management (QIEM) (pp. 67-70). Location: ClujNapoca, ROMANIA.

Indrisov, A. B. (1997). Strategic planning and analysis of the effectiveness of innovation (p. 367). M.: Filinn. 
Militaru, G., \& Ionescu, S. (2011). TQM - the change in management system. In the Proceedings of the 7 th International Conference on Management of Technological Changes (pp. 37-40). Location: Alexandroupolis, GREECE.

Sava (Angheluta), T., \& Tuclea, F. (2011). The evolution and the benefits of quality management system certification ISO9000. In the Proceedings 1st International Conference on Quality and Innovation in Engineering and Management (QIEM) (pp. 207-210). Location: ClujNapoca, ROMANIA.

Shvets, V. E. (2009). On the determination of the impact and effectiveness of the QMS.2009. Methods of Quality Management, 6, 6-7.

Skripko, L. E. (2010). The methodology of estimating the cost of quality. Methods of Quality Management, 1, 14 .

Titu, M., Oprean, C., \& Grecu, D. (2011). Managing the activity of the aftersales departments in an organization which has implemented a system of quality management. In the Proceedings of the 7th International Conference on Management of Technological Changes (pp. 80-89) Location: Alexandroupolis, GREECE.

Zinchenko, V. I., \& Monastyrny, E. A. (2009). The concept and principles for the development and application of methods of integrated assessment and monitoring of innovative projects. Innovations, $6,58$.

\section{Copyrights}

Copyright for this article is retained by the author(s), with first publication rights granted to the journal.

This is an open-access article distributed under the terms and conditions of the Creative Commons Attribution license (http://creativecommons.org/licenses/by/3.0/). 